\title{
Assessing the Relationship Between Destination Image and Tourists' Loyalty Towards the Amusement Parks of Bangladesh: The Mediating Role of Tourists' Satisfaction and Moderating Role of Past Experience
}

\author{
Tauhid Ahmed Bappy ${ }^{1}$ \\ ${ }^{1}$ Department of Business Administration, Shanto Mariam University of Creative Technology, Dhaka, \\ Bangladesh \\ Correspondence: Tauhid Ahmed Bappy, Lecturer, Department of Business Administration, Shanto-Mariam \\ University of Creative Technology, House\# 11, Road\# 17/A, Sector\# 12, Uttara, Dhaka-1230, Bangladesh. Tel: \\ 88-017-3817-4705. E-mail: tauhidbappy@gmail.com
}

Received: August 1, 2019

doi:10.5539/ass.v15n9p87
Accepted: August 19, $2019 \quad$ Online Published: August 30, 2019

URL: https://doi.org/10.5539/ass.v15n9p87

\begin{abstract}
The amusement park industry embodies one of the indispensable parts of the hospitality and tourism industry progressing in accordance with the shifting preferences and trends in travel and tourism demand. The main purpose of this study is to assess the relationship between destination image and tourists' loyalty towards the amusement parks of Bangladesh. This is a descriptive study in which the author used judgmental sampling technique to gather quantitative data from 300 visitors of four amusement parks in Bangladesh namely Fanstasy Kingdom, Nandan Park, Vinnya Jagat, and Dreamland amusement park. The researcher used structural equation modeling to analyze the data. The findings suggest that destination image positively and significantly influences tourists' satisfaction. Furthermore, tourists' satisfaction, subsequently, results in visitors' loyalty towards amusement parks. However, the relationship between amusement park image and tourists' loyalty is mediated by tourists' satisfaction. Furthermore, it was found that past visit experience at the amusement parks does not moderate the relationship between destination image and tourists' satisfaction. The researcher believes that the findings and recommendations presented in this study will significantly encourage the amusement park marketers of Bangladesh to enhance their destination image to improve the satisfaction and loyalty levels of the visitors.
\end{abstract}

Keywords: destination image, tourists' loyalty, tourists' satisfaction, past experience, amusement parks

\section{Introduction}

Destination image has always been one of the most popular areas of travel and tourism research because it facilitates tourism destination marketers to adopt and implement crucial strategic marketing decisions (Rajesh, 2013). Destination image has been found to affect visitors' intention to choose a particular destination, tourists' loyalty, tourists' satisfaction as well as their post visit behavior (Baloglu, 2000; Hernández-Lobato, 2006; Chen \& Tsai, 2007; Ramseook-Munhurrun et al., 2015; Chen \& Phou, 2013; Chi \& Qu, 2008). Specifically, the image of an amusement park has been the focal point of research by the academicians all over the world (Haahti \& Yavas, 2004; Lin et al., 2007; Wu et al., 2018; Jin et al., 2015; Hapsari 2018). These days, amusement park marketing has turned into one of the crucial subsets of travel and tourism marketing because people all the over the world frequently visit these parks for the purpose of spending their vacation and pastime (Salamat \& Banik, 2013). Hence, understanding and unfolding the reasons why and how visitors decide to visit an amusement park, become satisfied and exhibit loyalty have become an issue of paramount importance in the promising and competitive tourism marketing scenario.

In Bangladesh, amusement park sector is experiencing the growth stage of its life cycle (Islam et al., 2018). Shishu Park was the first ever public entertainment park established in Bangladesh in 1987. Subsequently, inspired by the achievements of Shishu Park, several other private funded amusement parks were established namely Shishu Mela, Wonderland, Fantasy Kingdom, and Nandon Park in the capital city of Dhaka (Kazi, 2006; Islam et al., 2018). Outside Dhaka, Bangladeshi tourists have the opportunity to visit Foy's Lake in Chittagong, Vinnya Jagat in Rangpur, Shopnopuri in Dinajpur, Dreamland Amusement Park in Sylhet, and Dream Holiday 
Park in Narshingdi and so on. Vinnya Jagat Amusement Park, indeed, is the largest of all amusement parks situated in Bangladesh having more than 100 acres of land, thrilling rides for children, first ever planetarium in Bangladesh, statues and artifacts, replica of seven wonders of the world, 3 star hotel named "Dream Palace", gigantic swimming pool, beautiful mosque and above all huge collection of flower and natural trees (Khondker et al., 2012). Other amusement and theme parks providing similar modern offerings have unlocked an opportunity to build Bangladesh an attractive holiday destination (Newagebd, 2018).

These days, owing to growing level of rivalry among different amusement parks in Bangladesh, the marketers of these parks are compelled to improve their image in an effort to satisfy their visitors as well as to enhance their loyalty (Islam et al., 2018). Under these circumstances, it has become imperative for the marketers of amusement parks in Bangladesh to identify major antecedents of amusement park image and to determine the relative importance of park image on visitors' satisfaction and tourists' loyalty. Several studies in the past have assessed the interrelationship among constructs such as destination image, tourist satisfaction and tourist loyalty but those studies were carried from different cultural context or country's perspective. However, to the best of the author's knowledge, there has been a dearth of published empirical research works in this topic from the perspective of the amusement parks of Bangladesh. It is believed that this study will contribute further to our existing knowledge as the author has investigated the mediating role of satisfaction and moderating role of past experience in the relationship between amusement park image and visitors' loyalty. Furthermore, it is also expected that this study will act as a reference point for future studies in the amusement park sector of Bangladesh.

\subsection{Objectives of the Study}

Keeping the importance of this research problem in view, this study has been carried out to fulfill the following specific objectives:

- To develop and validate a model depicting the link between destination/amusement park image and tourists' loyalty towards the amusement parks of Bangladesh.

- To predict the satisfaction of amusement park visitors as a function of destination image.

- To investigate the mediating role of tourist's satisfaction in the relationship between destination image and tourist's loyalty towards amusement parks of Bangladesh.

- To check the moderating role of past visit experience in the relationship between destination image and tourist's satisfaction towards amusement parks of Bangladesh.

- To describe the implications for the marketers of amusement park in light of the findings of this study.

\section{Literature Review}

\subsection{Definition of Amusement Park}

Amusement park is a huge outdoor area that encompasses varieties of rides, shows, picnic spots and other entertainment facilities (Adams-Volpe, 1991). Clavé (2007) defined theme park as a centre which consists of rides, shows and other entertainment facilities. De Groote (2011) argued that amusement parks include rides and other amusement attractions designed to attract tourists and visitors at a large scale from all around the globe.

\subsection{Destination Image and Tourists' Satisfaction Relationship}

Destination image stands for tourist's common impression and feelings towards a particular destination (Ramseook-Munhurrun et al., 2015; Fakeye \& Crompton, 1991). It symbolizes a mixture of beliefs, feelings, impressions, and ideas that tourists associate with a specific tourist spot or a given place (Gover et al., 2007; Chen \& Tsai, 2007). In the context of this study, amusement park image refers to visitors' in general evaluations and perceptions with regard to amusement parks formed as a result of emotional reactions and preceding experiences or explicit information about theme parks (Haathi \& Yavas, 2004; Lin et al., 2007). Destination image has emerged as a pivotal element for predicting tourists' behavioral intention (Chen \& Tsai, 2007), satisfaction (Chi \& Qu, 2008), and loyalty (Cai et al., 2003)) in the numerous tourism marketing literatures. The Table 1 summarizes the factors influencing the image of a destination in light of several past literatures:

Tourists' satisfaction, on the other hand, signifies the extent to which perceived performance of a given tourism spot matches the expectations of the tourists (Kotler et al., 2017). If the performance falls short of expectations, customers or visitors happen to be dissatisfied and when the performance of a product or service (an amusement park, in the context of this study) exceeds expectations, customers or tourists will feel delighted (Kotler \& Armstrong, 2017). Furthermore, according to Oliver (1997), customer satisfaction can be viewed as "a judgment that a product or service provides a pleasurable level of consumption-related fulfillment." In fact, according to 
Ryan et al., (2010), the antecedents of satisfaction in the theme park settings are connected to the atmosphere of the park, the availability of exciting rides, degrees of crowding experienced, availability of resting places and affordable admission fees and so on and so forth.

Table 1. Determinants of Destination Image

\begin{tabular}{|c|c|}
\hline Factors influencing Destination Image & Sources \\
\hline $\begin{array}{l}\text { Attractions, Accessibility, Lodging, Dining, Environment, Shopping Events \& } \\
\text { Activities }\end{array}$ & Rajesh (2013) \\
\hline Travel Environment, Attractions, Events, Infrastructure, Sports & Ramseook-Munhurrun et al., (2015) \\
\hline $\begin{array}{l}\text { Natural and Scenic resources, Accessibility, Cultural Resources, Security, Night } \\
\text { Life and Entertainment and Quality/Price Ratio }\end{array}$ & $\begin{array}{l}\text { Bigné et al., (2001); Chen \& Tsai, } \\
\text { (2007); Chi \& Qu, (2008) }\end{array}$ \\
\hline $\begin{array}{l}\text { Motivations, Vacation Experience, Socio-Demographic Characteristics, Primary } \\
\text { and Secondary Information Sources, Cognitive Components, Affective } \\
\text { Components }\end{array}$ & Beerli \& Mertin (2004) \\
\hline
\end{tabular}

The relationship between destination image and tourist satisfaction is well documented in several previous studies. In accordance with $\mathrm{Wu}$ et al., (2018), theme park image is a positive and significant predictor of experiential satisfaction of the theme park visitors of Janfusan Fancyworld of Taiwan. Furthermore, water park image has a direct effect on visitors' satisfaction (Jin et al.,2015). Similarly, it has been found that cognitive and affective factors of overall destination image significantly influence visitors' theme park destination preferences and satisfaction. In addition, according to Ramseook-Munhurrun et al. (2015), the better the destination image, the greater tourist's satisfaction. Therefore, the researcher postulates:

H1: Destination image positively influences tourists' satisfaction towards amusement parks.

\subsection{Tourists' Satisfaction and Tourists' Loyalty Relationship}

Customer loyalty is a widely studied marketing construct which has been defined in a number of different ways by several authors in the past. Table 2 summarizes three famous definition of customer loyalty:

Table 2. Definitions of Loyalty

\begin{tabular}{cl}
\hline \multicolumn{1}{c}{ Authors } & Definition \\
\hline Bose and Rao (2011) & $\begin{array}{l}\text { Customer loyalty refers to the customer's commitment to do business with a specific organization } \\
\text { which affects in repeat purchases of goods and services of that organization. } \\
\text { Loyalty signifies a deeply held commitment to rebuy or re-patronize a preferred product or service } \\
\text { Oliver (1999) } \\
\text { in the future despite situational influences and marketing efforts having the potential to cause } \\
\text { switching behavior } \\
\text { Loyalty can be both attitudinal and behavioral. Attitudinal loyalty is reflected in customers' intention } \\
\text { to repurchase whereas behavioral loyalty is reflected in customers' behavioral outcomes such as } \\
\text { repeat purchases or act of recommendation. }\end{array}$ \\
\hline
\end{tabular}

Several studies in the past have provided empirical evidences with regard to the relationship between tourist satisfaction and tourists' loyalty. According to Lee et al., (2011), a positive relationship between tourist loyalty and tourist satisfaction in the context of Chinese tourist in Korea. Furthermore, tourists' satisfaction has a negative effect on tourist complaints and a positive influence on tourists' loyalty (Žabkar et al., 2010.) In the context of theme park, past studies reflect that satisfied and delighted tourists' have higher level of loyalty and revisit intention to the theme parks (Ali et al., 2018; Jin et al., 2015). Hence, the researcher can hypothesize:

H2: Tourists' satisfaction positively influences tourists' loyalty towards amusement parks.

\subsection{Mediating Role of Tourist Satisfaction}

A mediating variable serves as a mechanism through which independent variable or variables relate to dependent variable (Malhotra \& Dash, 2017). Baron \& kenney (1986) suggest that in an attempt to verify the mediating role of a variable, researchers firstly have to establish a statistically significant relationship between independent variable and dependent variable; secondly, the relationship between independent variable and mediating variable has to be statistically significant as well and finally, the relationship between independent and dependent variable has to be investigated in the presence of mediating variable. If previously established relationship between the predictor and outcome variable turns out to be insignificant, it will be a case of full mediation; otherwise there will be a case of partial mediation or no mediation (Baron \& kenney, 1986). The link between destination image and tourist loyalty has been established by numerous researchers in the past (Cai et al., 2003; Jin et al., 2015; Chi 
\& Qu, 2008; Zhang et al., 2014; Wu et al., 2018). Furthermore, tourist satisfaction has empirically been tested as a mediating variable in several previously conducted tourism and hospitality related studies (Chi \& Qu, 2008, Yoon \& Uysal, 2005). Prayag \& Ryan (2012) outlined that destination image is one of the key determinants that lead to visitors' loyalty but this relationship is mediated by satisfaction levels. In addition, it has been observed that the influence of destination image of Mauritius on travelers' loyalty is mediated by their satisfaction (Ramseook-Munhurrun et al., 2015). Besides, Hapsari (2018) conducted a study in the context of two Indonesian theme parks and found that both theme parks' educational image and perceived value have an indirect effect on loyalty through satisfaction. Hence, the researcher can posit:

H3: Tourists' satisfaction mediates the positive effect of destination image on tourists' loyalty towards the amusement parks of Bangladesh.

\subsection{Moderating Effect of Past Visit Experience}

An amusement park always focuses on developing a memorable experience for its visitors (Trischler \& Zehrer, 2012). Past visit experience refers to "a past personal travel-related event strong enough to have entered long term memory" (Larsen, 2007; Park \& Santos, 2017). Another definition proposes that tourist past experience indicates a visitor's subjective evaluation of events with regard to the tourist behaviors which start prior to, during, and after the tour (Tung \& Richi, 2011; Bagdre, 2016).

However, tourist past experience has been used as a key moderating variable in several studies in the past (Rajaratnam et al., 2014; Pappas et al., 2014). A moderator is a variable that influences the strength of relationship between a predictor and an outcome variable (Cohen et al., 2014)). Jin et al., (2015) suggest that the effects of water park image on visitors' satisfaction significantly vary between first-time visitors and experienced repeat visitors. Furthermore, past experience is found to have a moderating effect on the relationship between the overall image of the tourist destination and tourist's satisfaction (Rodríguez Molina et al., 2013). Therefore, based on the above discussion, the researcher has proposed the following hypothesis:

H4: Tourist past visit experience moderates the relationship between destination image and tourist satisfaction.

On the basis of the objectives of this study and review of literature, the researcher has proposed the following conceptual framework:

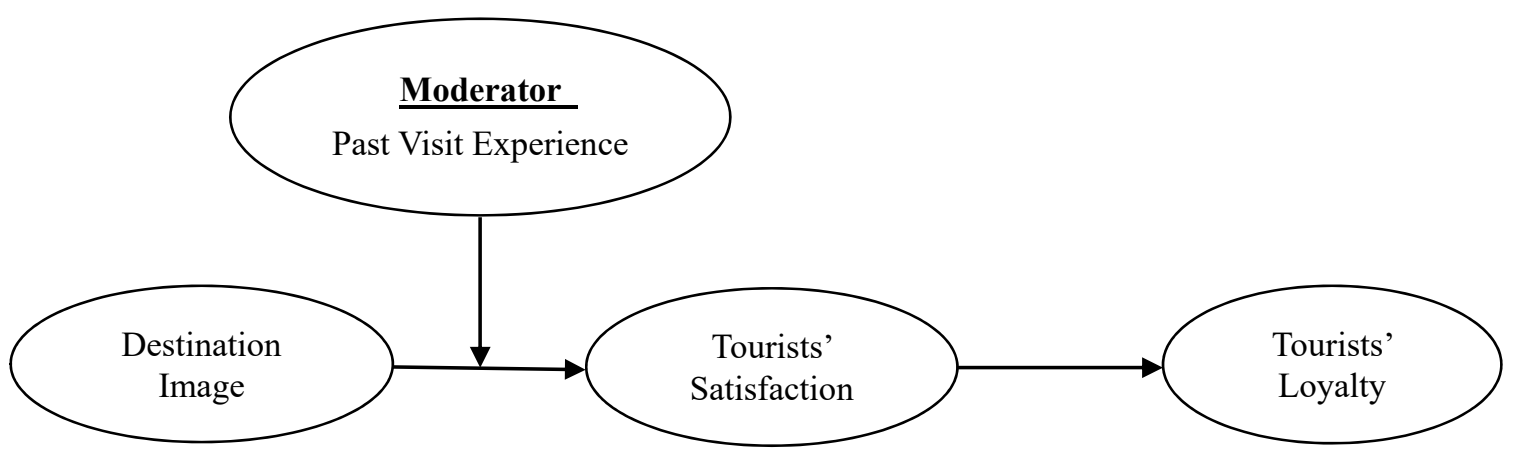

\section{Methodology}

Figure 1. Conceptual Framework

\subsection{Research Design}

A cross sectional descriptive study has been conducted by the researcher with a survey questionnaire which has been administered to multiple respondents and information from each respondent was gathered only once.

\subsection{Sources of Data}

Both primary and secondary sources of data are basically utilized to increase the meaningfulness and acceptability of a study (Haque, Bappy, \& Arifuzzaman, 2018). The primary data for this study have been obtained from the respondents by the researcher himself using a structured survey questionnaire. Review of different travel and tourism based established literatures and related newspaper articles with regard to amusement parks facilitated the researchers to accumulate the secondary data.

\subsection{Measurement and Scaling}

All the variables of this study have been estimated using multiple item based Likert scales with 5 response categories ranging from strongly disagree (1) to strongly agree (5). Most of the items measuring the latent 
constructs have been extracted from previous studies and modified to fit the context of the study. Latent constructs such as destination image, tourists' satisfaction have been measured by means of four indicators each. They have Cronbach's Alpha values of $.882, .905$ respectively. On the other hand, tourists' loyalty has been measured by using three items each. This construct presents an alpha value of .878 . Another variable "past visit experience" has been measured by means of a categorical scale $(1=$ fast time visit experience, $2=$ repeat visit experience). All the items and the sources from which they have been adopted are demonstrated in Appendix (1). Malhotra \& Dash (2015) is of the view that data obtained from Likert scale should be treated as interval. It was also reported that parametric tests can be used to examine Likert scale responses even when the assumption of normality is not fulfilled (Norman, 2010; Bappy et al., 2018).

\subsection{Target Population, Sampling Technique and Sample Size:}

The target population for this study involves the male and female amusement park visitors from several districts of Bangladesh such as Dhaka, Chittagong, Rangpur, and Sylhet. The whole study was conducted from December 01, 2018 to June 01, 2019.

Table 3. Sample Distribution

\begin{tabular}{ccc}
\hline Amusement Park & District & Respondents \\
\hline Fantasy kingdom & Dhaka & 70 \\
Nandon Park & Dhaka & 70 \\
Vinnya Jagat & Rangpur & 60 \\
Foy's lake & Chittagong & 50 \\
Dreamland Amusement Park & Sylhet & 50 \\
\hline
\end{tabular}

The researcher used judgmental sampling technique where respondents were selected on the basis of the judgment of the researcher. This technique was employed because of its low cost and convenience. Besides, it was very difficult for the researcher to prepare a sampling frame or a list of tourists within a short period. Furthermore, Hair et al., (2017) recommended the use of judgmental sampling when there is no sampling frame. The sample size was fixed to be 300 who were surveyed both online and offline. Sample size was computed based on the guidelines provided by Malhotra \& Das (2015). They suggest that structural equation models (SEM) with five or fewer constructs, each measured with at least three items, and communalities of at least .5 must be estimated with a sample size of minimum 200. In this study, the researcher has included three multi item constructs, each measured with at least three indicators each. Hence, it can be said that the sample size of 300 is acceptable for carrying out this study.

The questionnaire was initially formed in English and then it was translated into Bengali to ensure that the respondents understand the questionnaire items clearly. Initially, the questionnaire was handed over to 500 respondents. Out of which, 152 respondents provided incomplete answers. Among the rest, 301 respondents provided complete responses and 47questionnaires included erroneous responses and thus were eliminated.

\subsection{Data Analysis}

For data analysis, a confirmatory factor analysis (CFA) has been performed to assess the measurement model. In addition, with the use of path analysis, the researcher evaluated the hypothesized relationships proposed in the conceptual framework. The validity and reliability of the scales have been measured based on composite reliability, average variance extracted and other relevant statistics. Hence, structural equation modeling analysis using AMOS graphics has been used by the researcher. Besides, SPSS version 23 has also used to test the moderating effect of past visit experience in the relationship between destination image and tourists' satisfaction.

\section{Findings}

\subsection{Measurement Model}

Firstly, the researcher performed a confirmatory factor analysis (CFA) in an effort to test the measurement model outlined in the figure 2. The measurement model adopted in this study consists of three unobserved variables estimated by their respective items and these three constructs have been permitted to correlate independently with each other. This measurement model is an identified model because the number of distinct sample moments (66) turns out to be greater than the number of distinct parameters to be estimated (25) resulting in a positive degree of freedom (41). 


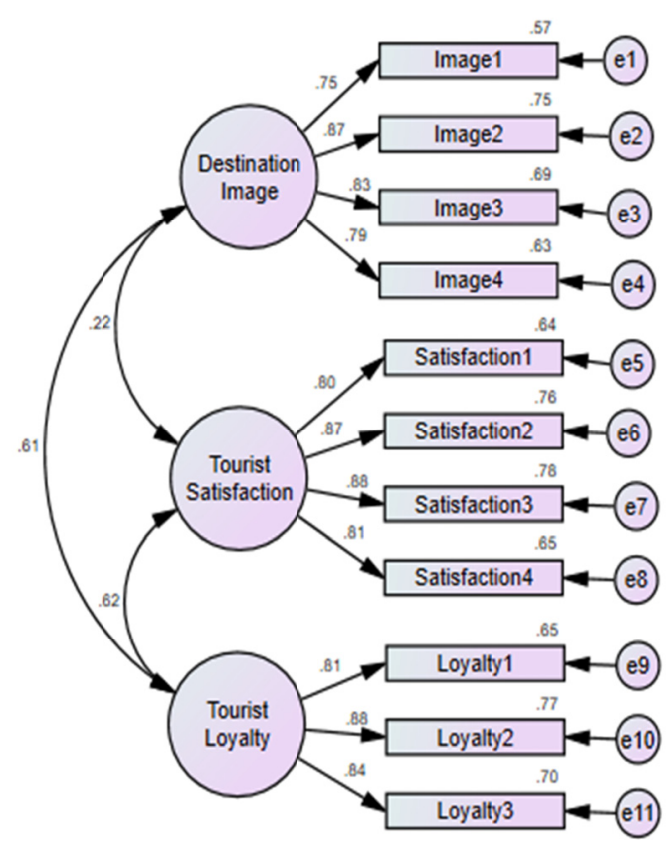

Figure 2. Measurement Model

Table 4. Goodness of Fit Statistics (Measurement Model)

Degree of Freedom $(\mathrm{df})=41$

Chi Square for independent model with 41 degrees of freedom $=71.085$ with a $P$ value of .002

Root Mean Square Error of Approximation (RMSEA) $=.050$

Root Mean Square Residuals $(\mathrm{RMR})=.028$

Normed Fit Index (NFI) $=.968$

Comparative Fit Index $(\mathrm{CFI})=.986$

Goodness of Fit Index $(\mathrm{GFI})=.959$

As evident from Table 4, the fit of the three-construct measurement model is satisfactory. Model fit is determined on the basis of chi square statistic, three goodness-of-fit indices such as NFI, CFI \& GFI and two badness-of-fit indices such as RMSEA and RMR. As a rule of thumb, higher values above .95 are considered acceptable for NFI, CFI and GFI and lower vales below.08 are considered to be favorable for RMSEA and RMR (Malhotra \& Dash, 2015). Table 4 shows that the values of NFI (.968), CFI (.986) and GFI (.959) exceeded the threshold level of .95 and the values of RMSEA (.050) and RMR (.028) are lesser than .08 . These results are normally favorable apart from chi-square $\chi^{2}(41)=71.085(\mathrm{P}<.05)$ which has been found to be significant. However, Benter \& Bonett (1980) argued that while evaluating the overall fit of the model, the researcher should not rely only upon chi square since it is sensitive to sample size increases. Therefore, the researcher evaluated alternative fit-indices and found that hypothesized model robustly fits the empirical data collected for conducting this study.

Table 5. CFA Results of Measurement Model/Indicator Variable

\begin{tabular}{|c|c|c|c|c|c|c|}
\hline Construct & Scale Items & Factor Loadings & Composite Reliability & AVE & MSV & ASV \\
\hline \multirow{4}{*}{ Destination Image } & DI1 & 0.753 & .884 & .657 & .368 & .208 \\
\hline & DI2 & 0.865 & & & & \\
\hline & DI3 & 0.829 & & & & \\
\hline & DI4 & 0.792 & & & & \\
\hline \multirow{4}{*}{ Tourists' Satisfaction } & Sat1 & 0.802 & .907 & .712 & .383 & .215 \\
\hline & Sat2 & 0.874 & & & & \\
\hline & Sat3 & 0.884 & & & & \\
\hline & Sat4 & 0.808 & & & & \\
\hline \multirow{3}{*}{ Tourists' Loyalty } & Loyalty 1 & 0.809 & .880 & .710 & .383 & .376 \\
\hline & Loyalty 2 & 0.878 & & & & \\
\hline & Loyalty3 & 0.839 & & & & \\
\hline
\end{tabular}


Next, the researcher measured the reliability and validity of the constructs. Composite reliability of each construct is computed to measure the reliability of the scales. As a rule of thumb, composite reliabilities of .60 or above are considered to be adequate (Bagozzi \& Yi, 1988). In this study, all the composite reliabilities of each item of the latent constructs exceeded the suggested cut-off criterion of .60. In addition to reliability, the researcher measured the validity of the scales in terms of convergent validity and discriminant validity.

As evident from Table 5, all the factors loadings are significantly correlated and surpassed the cut-off value of .40 (Stevens, 2012) and the average variance extracted (AVE) of all constructs are greater the threshold level of .50 (Kline, 2015; Malhotra \& Dash, 2015). All these outcomes demonstrate ample evidences of convergent validity. On the other hand, to establish discriminant validity, maximum shared variance (MSV) and average shared variance (ASV) have to be lower than the average variance extracted (Hair et al., 2006). As evident from Table 5, the values of MSV and ASV are smaller than the values of AVE which provide empirical evidences for discriminant validity of the constructs. Overall, this measurement model seems suitable from the perspective of this study because there are empirical evidences of good model fit, reliability, convergent validity and discriminant validity.

\subsection{Structural Model}

In the next phase of the study, multiple indicators measuring several constructs were averaged to achieve the scores of different constructs that were consequently used in the path analysis for testing several hypotheses formulated to carry out this study.

Table 6. Path Analysis Results (Direct and Indirect Effects)

\begin{tabular}{ccc}
\hline & \multicolumn{2}{c}{ Standardized Path Coefficients } \\
\hline Path & Direct Effect & Indirect Effect \\
\hline Destination Image ---> Tourists' Satisfaction & $0.202^{*}$ & $0.471^{*}$ \\
Tourists' Satisfaction---> Tourists' Loyalty & & $0.095^{*}$ \\
Destination Image ---> Tourists' Loyalty & & \\
\hline
\end{tabular}

Note: $* \mathrm{P}<.05$; Significant

However, based on the results shown in Table 6, the researcher tested the hypothesized relationships of the constructs delineated in Figure 1.

H1 stated that destination (amusement park) image positively influences tourists' satisfaction towards amusement parks of Bangladesh. As shown in Table 6, the effect of destination (park) image on tourists' satisfaction is in the hypothesized path and it was statistically significant $(\beta=.202 ; p<.05)$. Hence, it can be reasonably concluded that this research hypothesis is strongly supported.

H2 assumed that tourists' satisfaction is positively related to tourists' loyalty towards amusement parks of Bangladesh. As indicated in Table 6, the influence of tourists' satisfaction on their loyalty towards amusement park is in hypothesized direction and it was statistically significant $(\beta=.471 ; \mathrm{p}<.001)$. As a result, the researcher could not reject the claim that highly satisfied tourists will more frequently visit the amusement parks of Bangladesh.

To examine the mediating influence of destination image on the tourists' loyalty as stated in H3, the researcher relied upon the steps recommended by Baron \& Kenny (1986). As shown in Table 6, indirect effect of destination image on tourists' loyalty through tourists' satisfaction is statistically significant $(\beta=.095 ; \mathrm{p}<.05)$ which means the positive effect destination image on tourists' loyalty is mediated by tourists' satisfaction. However, only the values of indirect effect do not provide conclusive evidence about the type of mediation. To find out whether there is full mediation or partial mediation, further analysis is required.

Table 7. Results of Hypothesis Testing for Evaluating the Mediating Effect of Tourists' Satisfaction

\begin{tabular}{|c|c|c|c|c|}
\hline Hypothesis & Causal Path & Path Coefficients & P Value & Results \\
\hline \multirow{2}{*}{$\mathrm{H} 3$} & $\begin{array}{c}\text { Destination Image ---> Tourists' Loyalty, when Tourists' } \\
\text { Satisfaction --> Tourists' Loyalty is constrained }\end{array}$ & $0.546^{* *}$ & 0.000 & \multirow{2}{*}{ Partial Mediation } \\
\hline & $\begin{array}{c}\text { Destination Image ---> Tourists' Loyalty, when Tourists' } \\
\text { Satisfaction --> Tourists' Loyalty opened }\end{array}$ & $0.451^{* *}$ & 0.000 & \\
\hline
\end{tabular}

Note: $* * \mathrm{P}<.05$ (Statistically Significant)

As shown in Table 7, after reviewing the conditions for mediation (Barron \& Kenny 1986), when the satisfaction was not connected to tourists' loyalty or the mediating path from satisfaction to tourists' loyalty was restrained, 
the direct effect of destination (park) image $(\beta=.546, \mathrm{P}<.05)$ on tourists' loyalty was statistically significant. It was previously seen from Table 6 that satisfaction $(\beta=.471 ; p<.001)$ is positively related to tourists' loyalty. However, previously significant direct effect of destination image on tourists' loyalty was still significant but reduced $(\beta=.451 ; \mathrm{p}<.05)$ when the mediating path from tourists' satisfaction to tourists' loyalty was opened. Based on these results, it can be concluded that tourists' satisfaction partially mediates positive the relationship between destination (park) image and tourists' loyalty. As shown in figure 3, since $\mathrm{H} 1$ and $\mathrm{H} 2$ are fully supported and $\mathrm{H} 3$ is partially supported, the path destination image $\rightarrow$ tourists' satisfaction $\rightarrow$ tourists' loyalty can be established.

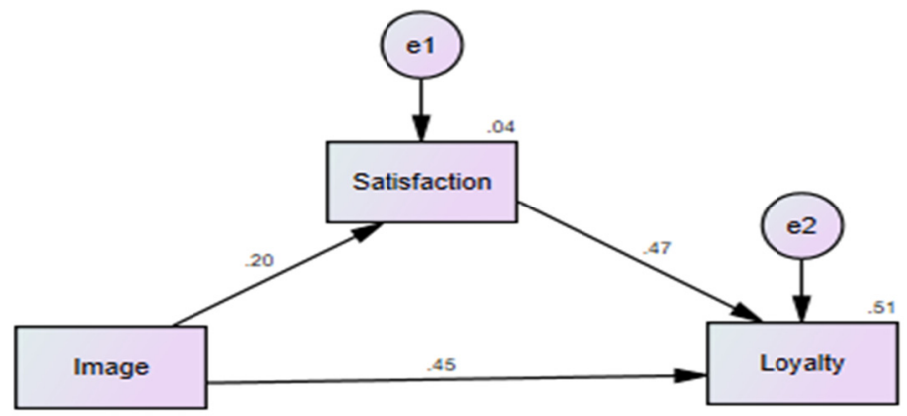

Figure 3. Structural Model

Table 8. Results of Moderated Regression Analysis

\begin{tabular}{|c|c|c|c|c|c|c|c|}
\hline \multicolumn{8}{|c|}{ Coefficients $^{\mathrm{a}}$} \\
\hline \multirow{2}{*}{ Past Experience } & \multirow{2}{*}{\multicolumn{2}{|c|}{ Model }} & \multicolumn{2}{|c|}{ Unstandardized Coefficients } & \multirow{2}{*}{$\frac{\text { Standardized Coefficients }}{\text { Beta }}$} & \multirow{2}{*}{$\mathrm{t}$} & \multirow{2}{*}{ Sig. } \\
\hline & & & $\mathrm{B}$ & Std. Error & & & \\
\hline \multirow{2}{*}{ First time visit } & \multirow{2}{*}{1} & (Constant) & 2.791 & .322 & & 8.674 & .000 \\
\hline & & Image & .267 & .081 & .261 & 3.283 & .001 \\
\hline \multirow{2}{*}{ Repeat Visit } & \multirow{2}{*}{1} & (Constant) & 3.350 & .375 & & 8.942 & .000 \\
\hline & & Image & .142 & .091 & .127 & 1.561 & .121 \\
\hline
\end{tabular}

Significance of the Difference between Two Slopes

t-value: 1.02603884

df: 296

P value: 0.30571104

a. Dependent Variable: Satisfaction

To test the moderation effect, the author relied on an online calculator in an attempt to ascertain whether the slopes of two lines (first time visit versus repeat visit) are significantly different from each other, given the slope, standard error, and sample size for each line (Sopher, 2019). Applying the values of sample size, beta coefficients, and standard errors as shown in Table 8 in Daniler Sopher's online calculator, the author obtained the $\mathrm{z}$ value of 1.03 which is lesser than the cut-off value of 1.96 and its associated $\mathrm{p}$ value (.301) was found to be greater than .05 . The decision rule is if $\mathrm{t}<1.96$, there is no moderation effect (Cohen et al., 2014). As a result, the data obtained from this study could not accept H4. Therefore, it can be concluded that the relationship between destination image and satisfaction is the same for both the groups with first time visit experience and repeated visit experience.

\section{Discussion and Implications}

The empirical outcomes of this study have established our belief and contributed to the existing knowledge that tourist satisfaction is the generic mediating instrument by means of which the image of a destination such as amusement park can positively influence the loyalty of the visitors. The current study uncovers that the destination image positively influences tourists' satisfaction. This result is consistent with the results of previous studies conducted in this field (Chon, 1990; Wu et al., 2018; Jin et al., 2015; Ramseook-Munhurrun et al., 2015). This empirical effect of destination image on visitors' satisfaction with amusement park has extremely solid and pragmatic implications for the amusement park marketers in Bangladesh. The amusement park authorities can enhance their image by means of ensuring modern and quality infrastructures such as thrilling and enjoyable rides, accommodation facilities, swimming pools, artifacts, shopping facilities, restaurants, theaters, concerts, attractive trees and so on. Moreover, the park management ought to consider the safety and pricing issues of the 
visitors to improve their image (Bappy \& Samiya, 2018; Kazi, 2006; Khondkar et al., 2012). If the overall park image can be enhanced, visiting amusement parks will be a satisfying experience for the visitors (Bappy \& Samiya, 2018; Newagebd, 2018; Islam et al; 2018). This study also reveals that tourist satisfaction is positively related to the loyalty of the park visitors which signifies the fact that satisfied tourists is likely to exhibit repeat visit intention to the parks and are mostly likely to recommend their positive experiences to their kith and kin. This result also matches the results of previous studies (Valle et al., 2006; Lee et al., 2011; Žabkar et al., 2010; Chi \& Qu, 2008) Hence, the marketers of amusement parks should constantly monitor the tourists' satisfaction levels with respect to various services of the parks. In order to generate more loyalty, marketers can arrange special frequency reward programs for the ones who repeatedly visit the parks and spend in larger amounts. The reward programs can involve flexible pricing, free rides, discounts in cottage booking or hotel services for the loyal tourists. However, this study identifies that whether a tourist has first time visit experience or repeat visitor experience, the influence of destination image on tourists' satisfaction happen to be the same for both the groups. This result, however, is different from the previous studies (Jin et al., 2015; Rodríguez Molina et al., 2013). Therefore, it is recommended that destination image be equally communicated to all types of tourists irrespective of their past visit experience.

\section{Conclusion}

The study examines the interrelation between destination image and tourists' satisfaction which ultimate results in tourists' loyalty towards the amusement parks of Bangladesh. In this era of cutthroat rivalry, an integrated approach and attention towards theme-based amusement parks can result in a major boost to the domestic tourism of Bangladesh, catching the attention of larger number of foreign tourists. Besides, in order to achieve the sustainability development goal of sustainable cities and communities (SDG-11), amusement parks can play a significant role. Hence, the image of amusement parks of Bangladesh must be improved by incorporating modern facilities and removing the mismanagements. On the other hand, satisfied and loyal amusement park visitors will frequently visit the parks, spend in greater amount, choose amusement parks over the other choices of destination, and will recommend the park to their nearest and dearest ones.

However, the present study bears some limitation with respect to sampling. This study incorporates a non-probability sampling technique due to unavailability of any sampling frame of amusement park visitors. This technique of choosing samples is subjective in nature. Besides, there are hundreds of amusement parks in Bangladesh but this study covers respondents from only four amusement parks. Although they are representative of the population, it may reduce the scope of generalization. The study does not show how customer loyalty or satisfaction varies with respect to the demographic characteristics of the respondents. This study involves only one predictor of tourist satisfaction. Further studies in this topic might include other variables such as attitude towards amusement park, service quality, perceived value, service marketing mix elements and so on to predict tourists' satisfaction and loyalty. Despite having some limitations, this is the first study in the context of Bangladesh which attempts to explain the relationship between destination image and tourist loyalty by checking the mediating effect of tourists' satisfaction and moderating effect of past visit experience. Overall, it is believed that this paper will act as a stepping stone for future studies in the amusement park sector of Bangladesh.

\section{References}

Adams-Volpe, J. (1991). The American amusement park industry: A history of technology and thrills. https://doi.org/10.2307/2078566

Alegre, J., \& Garau, J. (2010). Tourist satisfaction and dissatisfaction. Annals of tourism research, 37(1), 52-73. https://doi.org/10.1016/j.annals.2009.07.001

Ali, F., Kim, W. G., Li, J., \& Jeon, H. M. (2018). Make it delightful: Customers' experience, satisfaction and loyalty in Malaysian theme parks. Journal of Destination Marketing \& Management, 7, 1-11. https://doi.org/10.1016/j.jdmm.2016.05.003

Bagdare, S. (2016). A conceptual framework for management of tourism experience. Imperial Journal of Interdisciplinary Research, 2(6), 718-722.

Bagozzi, R. P., \& Yi, Y. (1988). On the evaluation of structural equation models. Journal of the academy of marketing science, 16(1), 74-94. https://doi.org/10.1007/BF02723327

Baloglu, S. (2000). A path analytic model of visitation intention involving information sources, socio-psychological motivations, and destination image. Journal of Travel \& Tourism Marketing, 8(3), 81-90. https://doi.org/10.1300/J073v08n03_05

Bappy, T. A., Haque, S. S., \& Halim, S. B. (2018). University students' shopping behavior for beauty soap 
brands in Bangladesh: A comparison of attitude towards foreign versus local brand. Asian Journal of Management Sciences \& Education, 7(4), 59-70.

Bappy, T. A., \& Halim, S. B. (2018). The Impact of Service Quality Dimensions on Visitors' Satisfaction towardss the Theme Parks of Bangladesh: An Empirical Study on Fantasy Kingdom Based on SEVQUAL Model. The AIUB Journal of Business and Economics, 15(1), 62-80.

Beerli, A., \& Martin, J. D. (2004). Factors influencing destination image. Annals of tourism research, 31(3), 657-681. https://doi.org/10.1016/j.annals.2004.01.010

Bentler, P. M., \& Bonett, D. G. (1980). Significance tests and goodness of fit in the analysis of covariance structures. Psychological bulletin, 88(3), 588. http://dx.doi.org/10.1037/0033-2909.88.3.588

Best, R. J., \& Coney, K. A. (1989). Consumer behavior: Implications for marketing strategy. McGraw-Hill/Irwin.

Bigné, J. E., Sánchez, M. I., \& Sánchez, J. (2001). Tourism image, evaluation variables and after purchase $\begin{array}{llll}\text { behaviour: } \quad \text { Inter-relationship. } & \text { Tourism }\end{array}$ https://doi.org/10.1016/S0261-5177(01)00035-8

Bose, S., \& Rao, V. G. (2011). Perceived benefits of customer loyalty programs: Validating the scale in the Indian context. Management \& Marketing, 6(4), 543-560.

Cai, L. A., Wu, B. T., \& Bai, B. (2003). Destination image and loyalty. Tourism Review International, 7(3-4), 153-162. https://doi.org/10.3727/1544272031437656

Chen, C. F., \& Phou, S. (2013). A closer look at destination: Image, personality, relationship and loyalty. Tourism management, 36, 269-278. https://doi.org/10.1016/j.tourman.2012.11.015

Chen, C. F., \& Tsai, D. (2007). How destination image and evaluative factors affect behavioral intentions? Tourism management, 28(4), 1115-1122. https://doi.org/10.1016/j.tourman.2006.07.007

Chi, C. G.-Q. \& Qu, H. (2008). Examining the structural relationships of destination image, tourist satisfaction and destination loyalty: An integrated approach. Tourism Management, 29, 624-636. https://doi.org/10.1016/j.tourman.2007.06.007

Chon, K. S. (1990). The role of destination image in tourism: A review and discussion. The tourist review, 45(2), 2-9. https://doi.org/10.1108/eb058040

Clavé, S. A. (2007). The global theme park industry. https://doi.org/10.1079/9781845932084.0000

Cohen, P., West, S. G., \& Aiken, L. S. (2014). Applied multiple regression/correlation analysis for the behavioral sciences. Psychology Press. https://doi.org/10.4324/9781410606266

De Groote, P. (2011). Globalisation of Commercial Theme Parks Case: The Walt Disney Company. APSTRACT: Applied Studies in Agribusiness and Commerce, 5(3), 21-28.

Do Valle, P. O., Silva, J. A., Mendes, J., \& Guerreiro, M. (2006). Tourist satisfaction and destination loyalty intention: A structural and categorical analysis. International Journal of Business Science \& Applied Management (IJBSAM), 1(1), 25-44. http://hdl.handle.net/10419/190577

Fakeye, P. C., \& Crompton, J. L. (1991). Image differences between prospective, first-time and repeat visitors to the Lower Rio Grande Valley. Journal of Travel Research, 30(2), 10-16. https://doi.org/10.1177/004728759103000202

Govers, R., Go, F., \& Kumar, K. (2007). Promoting Tourism Destination Image. Journal of Tourism Research, 14(2), 234-256. https://doi.org/10.1177/0047287507302374

Haahti, A., \& Yavas, U. (2004). A multi-attribute approach to understanding image of a theme park: The case of SantaPark in Lapland. European Business Review, 16(4), 390-397. https://doi.org/10.1108/09555340410547026

Hair, J. F., Black, W. C., Babin, B. J., Anderson, R. E., \& Tatham, R. L. (2006). Multivariate data analysis (Vol. 6), Upper Saddle River, NJ: Pearson Prentice Hall.

Hair, J. F., Hult, G. T. M., Ringle, C. M., Sarstedt, M., \& Thiele, K. O. (2017). Mirror, mirror on the wall: A comparative evaluation of composite-based structural equation modeling methods. Journal of the Academy of Marketing Science, 45(5), 616-632. https://doi.org/10.1007/s11747-017-0517-x

Hapsari, R. (2018). Creating Educational Theme Park Visitor Loyalty: The Role of Experience-Based 
Satisfaction, Image and Value. Tourism and hospitality management, 24(2), 359-274. https://doi.org/10.20867/thm.24.2.7

Haque, M. S. S., Bappy, T. A., \& Arifuzzaman, M. (2018). The Impact of Brand Awareness on Customer Loyalty towardss Igloo Ice Cream: A Study on Dhaka University Students. International Journal of Science and Business, 2(1), 1-21. https://doi.org/10.5281/zenodo.1136274

Hernández-Lobato, L., Solis-Radilla, M. M., Moliner-Tena, M. A., \& Sánchez-García, J. (2006). Tourism destination image, satisfaction and loyalty: A study in Ixtapa-Zihuatanejo, Mexico. Tourism geographies, 8(4), 343-358. https://doi.org/10.1080/14616680600922039

Islam, N., Islam, T., Abbas, S. M., Huda, R. B., Tabassum, A., \& Mubassira, Q. N. (2018). Visitors' Perception about the Entertainment Parks in Dhaka City of Bangladesh. Available at SSRN 3304665. https://dx.doi.org/10.2139/ssrn.3304665

Jin, N., Lee, S., \& Lee, H. (2015). The effect of experience quality on perceived value, satisfaction, image and behavioral intention of water park patrons: New versus repeat visitors. International Journal of Tourism Research, 17(1), 82-95. https://doi.org/10.1002/jtr.1968

Khondkar, M., Pathak, K. P., \& Anis, A. (2012). Success Factors of Place Marketing: A Study on Vinnya Jagat. Journal of Business, 33(1).

Kline, R. B. (2015). Principles and practice of structural equation modeling. Guilford publications. https://doi.org/10.1080/10705511.2012.687667

Kozak, M., \& Rimmington, M. (2000). Tourist satisfaction with Mallorca, Spain, as an off-season holiday destination. Journal of travel research, 38(3), 260-269. https://doi.org/10.1177/004728750003800308

Lee, S., Jeon, S., \& Kim, D. (2011). The impact of tour quality and tourist satisfaction on tourist loyalty: The case of Chinese tourists in Korea. Tourism Management, 32(5), 1115-1124. https://doi.org/10.1016/j.tourman.2010.09.016

Lin, C. H., Morais, D. B., Kerstetter, D. L., \& Hou, J. S. (2007). Examining the role of cognitive and affective image in predicting choice across natural, developed, and theme-park destinations. Journal of Travel Research, 46(2), 183-194. https://doi.org/10.1177/0047287506304049

Malhotra Naresh, K., \& Dash, S. (2015). Marketing Research, An Applied Orientation, 7e. Pearson India.

Newagebd. (2018). Modern amusement and theme parks can make BD a good holiday destination. Retrieved from http://www.newagebd.net/article/47596/modern-amusement-and-theme-parks-can-make-bd-a-goodholiday-destination

Norman, G. (2010). Likert scales, levels of measurement and the "laws" of statistics. Advances in health sciences education, 15(5), 625-632. https://doi.org/10.1007/s10459-010-9222-y

O. Pappas, I., G. Pateli, A., N. Giannakos, M., \& Chrissikopoulos, V. (2014). Moderating effects of online shopping experience on customer satisfaction and repurchase intentions. International Journal of Retail \& Distribution Management, 42(3), 187-204. https://doi.org/10.1108/IJRDM-03-2012-0034

Oliver, R. L. (1999). Whence consumer loyalty? Journal of Marketing, 63(4_suppl1), 33-44. https://doi.org/10.1177/00222429990634s105

Park, S., \& Santos, C. A. (2017). Exploring the tourist experience: A sequential approach. Journal of Travel Research, 56(1), 16-27. https://doi.org/10.1177/0047287515624017

Prayag, G., \& Ryan, C. (2012). Antecedents of tourists' loyalty to Mauritius: The role and influence of destination image, place attachment, personal involvement, and satisfaction. Journal of travel research, 51(3), 342-356. https://doi.org/10.1177/0047287511410321

Rajaratnam, S. D., Munikrishnan, U. T., Sharif, S. P., \& Nair, V. (2014). Service quality and previous experience as a moderator in determining tourists' satisfaction with rural tourism destinations in Malaysia: A partial least squares approach. Procedia-Social and Behavioral Sciences, 144, 203-211. https://doi.org/10.1016/j.sbspro.2014.07.288

Rajesh, R. (2013). Impact of tourist perceptions, destination image and tourist satisfaction on destination loyalty: A conceptual model. PASOS. Revista de Turismo y Patrimonio Cultural, 11(3), 67-78. https://doi.org/10.25145/j.pasos.2013.11.039

Ramseook-Munhurrun, P., Seebaluck, V. N., \& Naidoo, P. (2015). Examining the structural relationships of 
destination image, perceived value, tourist satisfaction and loyalty: Case of Mauritius. Procedia-Social and Behavioral Sciences, 175, 252-259. https://doi.org/10.1016/j.sbspro.2015.01.1198

Rodríguez Molina, M. Á., Frías-Jamilena, D. M., \& Castañeda-García, J. A. (2013). The moderating role of past experience in the formation of a tourist destination's image and in tourists' behavioural intentions. Current issues in tourism, 16(2), 107-127. https://doi.org/10.1080/13683500.2012.665045

Ryan, C., Shih Shuo, Y., \& Huan, T. C. (2010). Theme parks and a structural equation model of determinants of visitor satisfaction-Janfusan Fancyworld, Taiwan. Journal of Vacation Marketing, 16(3), 185-199. https://doi.org/10.1177/1356766710372245

Salamat Ullah Bhuiyan, S. M., \& Banik, S. (2013). Amusement Marketing: A Few Dimensions of Amusement Parks. International Journal of Business Insights \& Transformation, 7(1), 36-41.

Soper, D. S. (2019). Significance of the Difference between Two Slopes Calculator [Software]. Retrieved from http://www.danielsoper.com/statcalc

Stevens, J. P. (2012). Applied multivariate statistics for the social sciences. https://doi.org/10.2307/1164712

Swarbrooke, J., \& Horner, S. (2007). Consumer behaviour in tourism. https://doi.org/10.4324/9780080466958

Trischler, J., \& Zehrer, A. (2012). Service design: Suggesting a qualitative multistep approach for analyzing and examining theme park experiences. Journal of Vacation Marketing, 18(1), 57-71. https://doi.org/10.1177/1356766711430944

Tsiotsou, R. H., Ratten, V., Byon, K. K., \& Zhang, J. J. (2010). Development of a scale measuring destination image. Marketing Intelligence \& Planning, 28(4), 508-532. https://doi.org/10.1108/02634501011053595

Wu, H. C., Li, M. Y., \& Li, T. (2018). A study of experiential quality, experiential value, experiential satisfaction, theme park image, and revisit intention. Journal of Hospitality \& Tourism Research, 42(1), 26-73. https://doi.org/10.1177/1096348014563396

Yoon, Y., \& Uysal, M. S. (2005). An examination of the effects of motivation and satisfaction on destination $\begin{array}{lllll}\text { loyalty: A structural model. Tourism } & \text { Management, 26(1), 45-56. }\end{array}$ https://doi.org/10.1016/j.tourman.2003.08.016

Žabkar, V., Brenčič, M. M., \& Dmitrović, T. (2010). Modelling perceived quality, visitor satisfaction and behavioural intentions at the destination level. Tourism management, 31(4), 537-546. https://doi.org/10.1016/j.tourman.2009.06.005

Zhang, H., Fu, X., Cai, L. A., \& Lu, L. (2014). Destination image and tourist loyalty: A meta-analysis. Tourism management, 40, 213-223. https://doi.org/10.1016/j.tourman.2013.06.006

Appendix A: Psychometric Properties of the Measurement Model.

\begin{tabular}{clc}
\hline Constructs & Summary of Scale Items Used in this Study & References \\
\hline \multirow{2}{*}{$\begin{array}{c}\text { Destination } \\
\text { Image }\end{array}$} & $\begin{array}{l}\text { The amusement park has excellent natural attractions (trees, flowers \& green grass) } \\
\text { The park has quality infrastructure (Cleanliness, rides, accommodations \& artifacts) }\end{array}$ & $\begin{array}{c}\text { Tsiotsou et al., } \\
\text { Amusement parks of Bangladesh is a pleasing and enjoyable travel destination }\end{array}$ \\
& I believe I am satisfied with the services of amusement park of Bangladesh. & Chi \& Qu, 2008 \\
Tourists' & $\begin{array}{l}\text { Overall, I am pleased with our amusement parks. } \\
\text { Satisfaction }\end{array}$ & Visiting amusement parks is usually a satisfactory experience \\
& My feelings towards the amusement parks of our country are not dissatisfactory. & \\
\hline $\begin{array}{c}\text { Tourists' } \\
\text { Loyalty }\end{array}$ & $\begin{array}{l}\text { I will continue to visit and patronize this amusement park. } \\
\text { I have an intention to visit this amusement park in future }\end{array}$ & $\begin{array}{c}\text { Ramseook-Munh } \\
\text { urrun et al., 2015 }\end{array}$ \\
\hline
\end{tabular}

\section{Copyrights}

Copyright for this article is retained by the author(s), with first publication rights granted to the journal.

This is an open-access article distributed under the terms and conditions of the Creative Commons Attribution license (http://creativecommons.org/licenses/by/4.0/). 